\title{
Avaliação biomecânica dos tendões dos músculos tibiais e proposta de sua utilização como aloenxertos nas reconstruções do ligamento cruzado anterior \\ Biomechanical evaluation of tibial muscle tendons and proposal of their use as allografts in anterior cruciate ligament reconstructions
}

\author{
Alexandre de Christo Viegas ${ }^{1}$; Gilberto Luis Camanho ${ }^{2}$
}

\section{RESUMO}

Com o objetivo de avaliar as propriedades mecânicas dos tendões dos músculos tibial anterior (TA) e tibial posterior (TP), o autor realizou ensaios mecânicos com tendões extraídos de 18 cadáveres humanos frescos, do sexo masculino, com média de idade de $45,2 \pm 10,7$ anos. Os tendões foram divididos em dois grupos e armazenados a $-20^{\circ} \mathrm{C}$ e a $-86^{\circ} \mathrm{C}$ durante 30 a 90 dias antes dos testes. Depois de descongelados, foram feitas medidas da área de secção transversa dos tendões e ensaios mecânicos de tração até a ruptura a uma velocidade de aplicação de carga de $20 \mathrm{~mm} / \mathrm{min}$. Foram determinadas as seguintes propriedades biomecânicas: resistência máxima, coeficiente de rigidez, módulo de elasticidade e alongamento máximo relativo; os dados obtidos foram comparados aos existentes na literatura relativos ao ligamento cruzado anterior (LCA) e seus substitutos mais utilizados. A comparação dos dados obtidos neste estudo com os estudos biomecânicos feitos por outros autores nos permitiu obsenvar que o TA e o TP apresentam propriedades mecânicas que os tomam possíveis substitutos do LCA nos casos em que a necessidade de enxertos alógenos se impuser.

Descritores: J oelho; Ligamento cruzado anterior; Artroscopia; Tendões.

\section{INTRODUÇÃO}

As lesões ligamentares do joelho são um evento freqüente na traumatologia e seu tratamento por meio da reconstrução dos ligamentos com o uso de enxertos tendinosos é um consenso na literatura atual. A utilização de enxertos homólogos como o ligamento da patela (LP), os tendões dos músculos flexores mediais do joelho (semitendíneo e grácil) e o tendão quadricipital são operações consagradas para este fim ${ }^{(2,5)}$.

As lesões ligamentares múltiplas do joelho, as reconstruções em pacientes com traumatismos graves do membro infe-

\section{SUMMARY}

The purpose of this study was to evaluate the mechanical properties of the anterior (AT) and posterior (PT) tibialis muscle tendons submitted to axial strain until the point of ultimate failure, at a $20 \mathrm{~mm} / \mathrm{min}$ speed. We used fresh-frozen human tendons from 18 male cadavers with mean age of $45.2 \pm 10.7$ years. The tendons were divided into two groups and one was frozen at $20^{\circ} \mathrm{C}$ and the other at $-86^{\circ} \mathrm{C}$, for 30 to 90 days before the tests.

The tendons were thawed then the cross sectional area at their central portion was measured. We studied the following mechanical properties: ultimate strength, rigidity, modulus of elasticity and relative strain (\%). The data obtained were compared with those found in the literature related to the anterior cruciate ligament $(A C L)$ and its common replacements. The comparison between AT and PT with results obtained by other authors showed that the tendons have biomechanical properties that make their use possible as $A C L$ grafts in cases of ligament reconstruction where allografts are usually employed.

Key Words: Knee; Anterior cruciate ligament; Arthroscopy; Tendons.

\section{INTRODUCTION}

Knee ligament injuries are frequent events in traumatology and their management by ligament reconstruction using tendinous grafts is a consensus in current literature. The use of homologous grafts, such as the patellar ligament (PL), the tendons of knee medial bending muscles (semitendinous and gracilis) and the quadriccipital tendon, are operations designed to this purpose ${ }^{(2,5)}$.

Knee multiple ligament injuries, reconstructions in patients with severe traumatisms in the lower limbs, and reviews of liga-
Trabalho realizado no Laboratório de Biomecânica do Instituto de Ortopedia e Traumatologia da Universidade de São Paulo

1- Mestrando do Instituto de Ortopedia e Traumatologia da Faculdade de Medicina da Universidade de São Paulo

2- Professor Associado da Faculdade de Medicina da Universidade de São Paulo

Endereço para correspondência: Rua Rodrigo Cláudio, 197 / 92 - Aclimação São Paulo - SP - CEP 01532-020 - e-mail: aleviegas@ uol.com.br

Trabalho recebido em 31/03/2003. Aprovado em 29/05/2003
This work was performed at the Laboratory of Biomechanics, Institute of Orthopedics and Traumatology, University of Sao Paulo

1- Working towards his Master's Degree at the Institute of Orthopedics and Traumatology, Faculty of Medicine, University of Sao Paulo (FMUSP), SP- Brazil 2- Associate Professor, FMUSP

Address: Rua Rodrigo Cláudio, 197 / 92 - Aclimação - São Paulo, SP - CEP 01532-020 Brazil - e-mail: aleviegas@uol.com.br 
rior e as revisões de reconstruções dos ligamentos estimularam o estudo de novas fontes de enxertos para substituir os ligamentos cruzados. Da mesma maneira, com o desenvolvimento das técnicas de obtenção e armazenamento dos tecidos alógenos e o surgimento dos bancos de tecido, teve início o estudo das propriedades mecânicas dos enxertos comumente utilizados nas reconstruções ligamentares. Estimulados com os resultados das reconstruções em casos excepcionais e amparados no avanço dos métodos utilizados nos bancos de tecido, alguns autores propuseram a utilização de aloenxertos como opção na reconstrução das lesões ligamentares do joelho(1,11).

Os resultados iniciais destas reconstruções na cirurgia do joelho fizeram com que o uso de aloenxertos se tomasse prática comum nas reconstruções de lesões ligamentares crônicas e agudas ${ }^{(9,10,13)}$. O objetivo deste trabalho é estudar as características mecânicas dos tendões dos músculos tibial anterior (TA) e tibial posterior (TP) de cadáveres humanos submetidos a congelamento e propor sua utilização como aloenxertos na reconstrução do ligamento cruzado anterior (LCA).

\section{MATERIAL E MÉTODO}

Utilizamos neste trabalho 18 pares de tendões dos músculos tibial anterior e tibial posterior extraídos de cadáveres humanos adultos do sexo masculino, com idade média de 45,2 \pm 10,7 anos, variando entre 24 e 60 anos. Foram obedecidas as normas éticas relativas ao uso de material humano do Serviço de Verificação de Óbitos da Capital, que nos forneceu o material para este estudo.

Os tendões foram extraídos em um período médio de 48 a 96 horas post mortem de cadáveres que eram mantidos em câmara frigorífica a uma temperatura de menos $4^{\circ} \mathrm{C}$.

Os tendões foram divididos em dois grupos de igual tamanho e permaneceram congelados a temperaturas de menos $20^{\circ} \mathrm{C}$ e menos $86^{\circ} \mathrm{C}$ em um período que variou de 30 a 90 dias, até que fossem realizados os ensaios mecânicos.

Antes dos ensaios mecânicos, as peças foram descongeladas em solução isotônica de cloreto de sódio, onde foram mantidas imersas durante quatro horas à temperatura ambiente até seu total descongelamento.

Em seguida, foi realizada a medição das peças anatômicas, a fim de se calcular a área de secção transversa da porção central do tendão e para este fim utilizamos um equipamento denominado projetor de perfil. Os tendões foram colocados entre duas placas de acrílico transparentes a fim de tornar sua área de secção transversa trapezoidal e o equipamento permitiu a medida dos lados deste trapézio e posteriormente o cálculo de sua área. (Figuras 1,2,3,4 e Tabela 1)

Os tendões foram submetidos a tração axial pura até sua ruptura completa na máquina eletromecânica Kratos (Figura 6), modelo K-5002, a uma velo- ment reconstructions have encouraged the investigation of new graft sources to replace cruciate ligaments. Likewise, with the development of techniques to obtain and store allogenic tissues, plus the emergence of tissue banks, a study was initiated of the mechanical properties of the grafts commonly employed in ligament reconstructions. Encouraged by the results obtained in reconstructions in exceptional cases, and based on the advancement of the methods employed in tissue banks, several authors proposed the use of allografts as an alternative in the reconstruction of knee ligament injuries ${ }^{(1,11)}$.

The early results of such reconstructions in knee surgery turned the use of allografts a common practice in the reconstruction of both chronic and acute ligament injuries $(9,10,13)$. The purpose of this study is to investigate the mechanical features of the tendons of the anterior tibial (AT) and posterior tibial (PT) muscles of frozen human cadavers, and propose their use as allografts in the reconstruction of the anterior cruciate ligament $(A C L)$.

\section{MATERIAL AND METHOD}

In this study we used 18 pairs of tendons of the anterior tibial and posterior tibial muscles from male adult human cadavers in the age group of 24 to 60 years and mean age of $45.2 \pm 10.7$ years. The study complied with the ethical standards relative to the use of human material issued by the Service of Death Checking of Sao Paulo city, which provided us with the material employed in this study.

The tendons were extracted during a mean post mortem period of 48 to 96 hours from cadavers kept at minus $4^{\circ} \mathrm{C}$ in a cold temperature chamber.

The tendons were divided into two groups of same size and maintained frozen at minus $20^{\circ} \mathrm{C}$ and minus $86^{\circ} \mathrm{C}$ for a period varying from 30 to 90 days until the mechanical tests were performed.

Before the mechanical tests, the pieces were immersed in an isotonic sodium chloride solution and left for 4 hours at room temperature until they were fully unfrozen.

Then the anatomical pieces were measured to calculate the cross sectional area of the tendon's central portion; for this, we used the so-called profile projector. The tendons were placed between two clear acrylic plates in order to turn their cross section trapezoidal; the equipment allowed

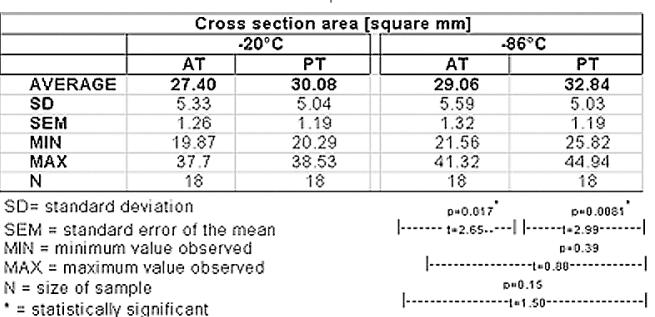
transversa, medida em milímetros quadrados, dos tendões dos músculos tibiais anteriores (TA) e tibiais posteriores (TP) congelados a $-20^{\circ} \mathrm{C}$ e a $-86^{\circ} \mathrm{C}$.

Table 1- Comparison of values of the cross section area (square $\mathrm{mm}$ ) of the anterior tibial muscle tendons (AT) and and at minus $86^{\circ} \mathrm{C}$.
Tabela 1- Comparação dos valores da Área de secção posterior tibial muscle tendons (PT) frozen at minus $20^{\circ} \mathrm{C}$ both sides of the trapeze to be measured, whose area was then calculated (Figures 1,2,3,4 and Table 1).

The tendons were subjected to pure axial strain until the ultimate strength was reached, as shown in the electromechanical Kratos machine model K-5002 (Figure 6) at a $20-\mathrm{mm} / \mathrm{min}$ constant speed. In each essay the load-deformation graph was obtained (Figure 5). The tendons were fixed to two metal clamps (Figure7) consisting of parallel metal plates with inner notches to avoid tendons to slide while the load is being applied (Figures 5,6 and 7). 


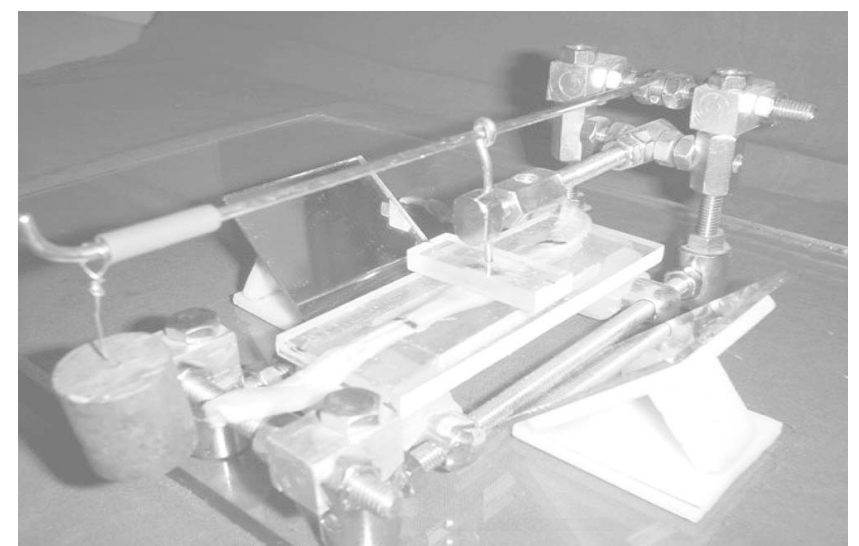

Figura 1 - Dispositivo de posicionamento do tendão para sua medição. Figure 1 - Device to position the tendon for measurement

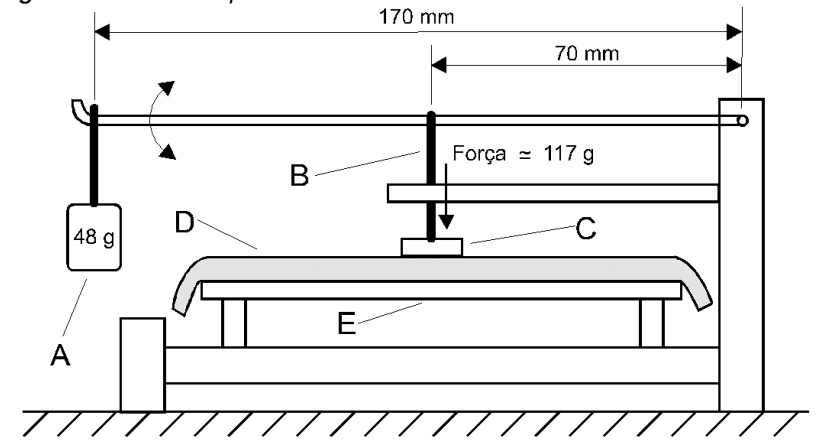

Figura 2- Modelo esquemático do dispositivo de posicionamento de tendão, onde: A-Peso de $48 \mathrm{~g}$; B-Haste transmissora de força; CParalelepípedo de acrílico transparente, que exerce uma força constante no tendão; D- Tendão; E- Mesa de apoio transparente.

Figure $\mathbf{2}$ - Schematic drawing of the positioning device to fix the tendon, where A- 48-g weight; B-Force-transmitting rod; C- Clear acrylic parallelepiped exerting a constant force on the tendon; D- Tendon; E- Clear supporting table.
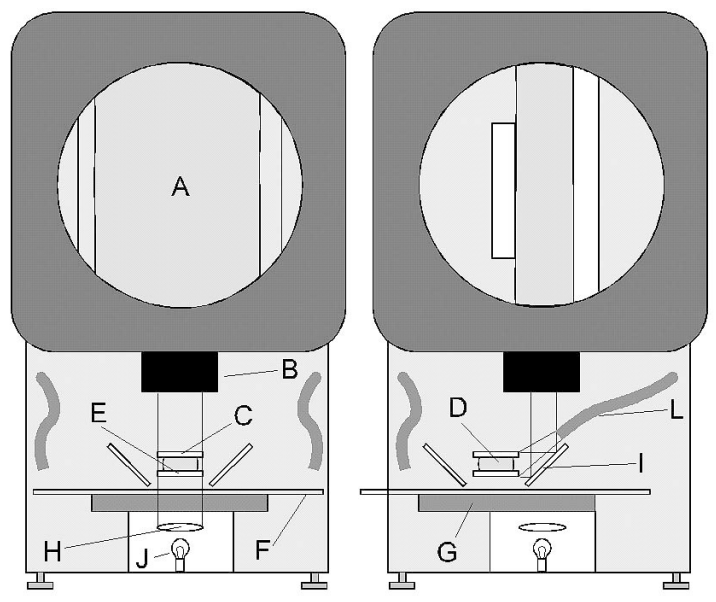

Figura 3 - Desenho esquemático da medição da área do tendão utilizando um projetor de perfil para visualização por raios refratados (à esquerda) e refletidos (à direita), onde: A- Imagem na tela do projetor; B- Lentes de magnificação; C- Paralelepípedo de acrílico; D- Tendão; E- Mesa de apoio; FMesa de vidro; G- Mesa do projetor com ajuste tridimensional; H- Lente colimadora; J-Lâmpada; L- Fibras ópticas ajustáveis acopladas a uma fonte luminosa.

Figure 3 - Schematic drawing of the tendon measuring process using a profile projector to view through refracted rays (to the left) and reflected rays (to the right), where A- Image displayed on the projector's screen; $\mathbf{B}$ Magnification lenses; C- Acrylic table; D- Tendon; E- Support table; F- Glass table; G- Projector's table with 3D adjustment; H-Collimating lens; J-Lamp; L- Adjusting optical fibers coupled to a light source

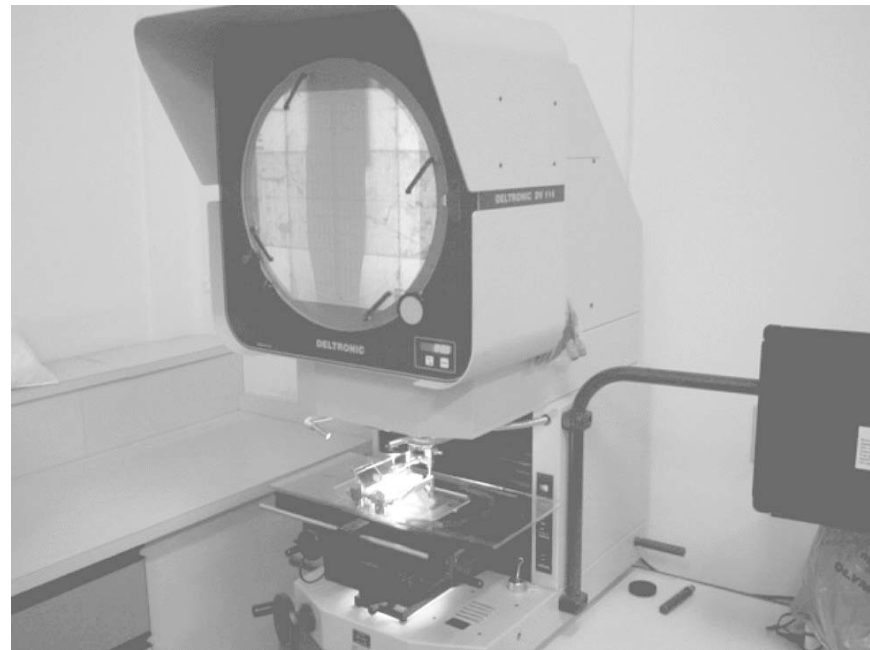

Figura 4 - Projetor de perfil / Figure 4 - Profile projector

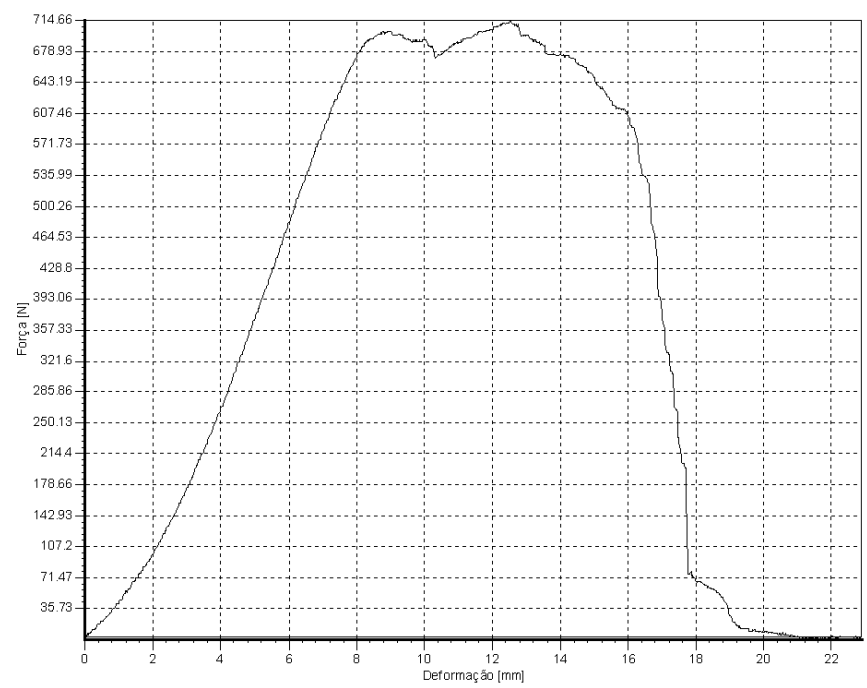

Figura 5 - Gráfico carga $[\mathrm{N}]$-deformação $[\mathrm{mm}]$ referente ao ensaio mecânico da amostra de número 13 (TA congelado a $-20^{\circ} \mathrm{C}$ )

Figure 5 - Load $(\mathrm{N})$ - Deformation $(\mathrm{g})$ graph $[\mathrm{mm}]$ relative to the mechanical essay on sample \# 13 (TA frozen at minus $20^{\circ} \mathrm{C}$ ).

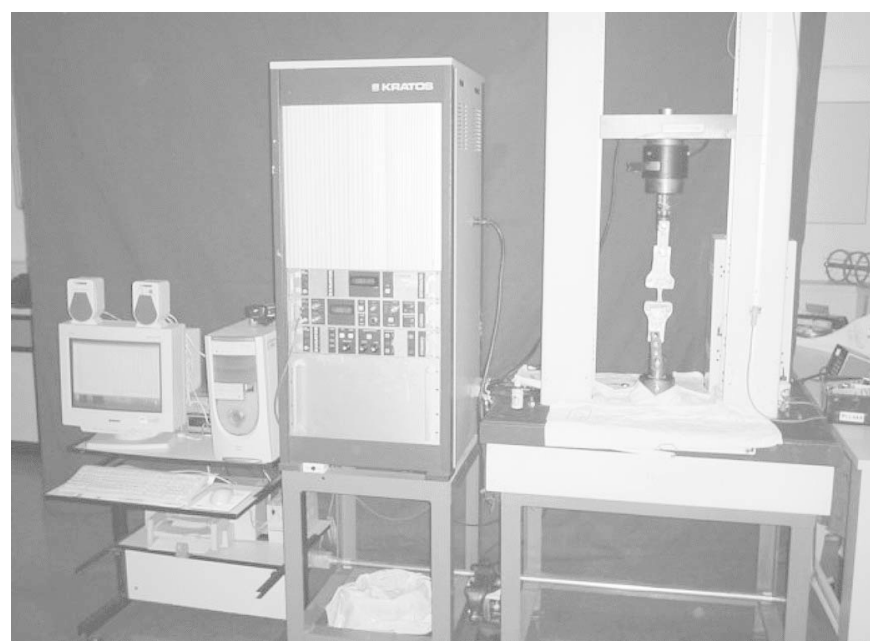

Figure 6 - Máquina de ensaios, painel de controles e microcomputador acoplado ao sistema.

Figure 6 - Testing machine, control display and a microcomputer coupled to the system 
cidade constante de $20 \mathrm{~mm} / \mathrm{min}$, obtendo-se para cada um dos ensaios o diagrama carga-deformação (Figura 5). Os tendões foram fixados a duas garras metálicas (Figura7) constituídas por placas metálicas paralelas com encaixe interno denteado para evitar o deslizamento dos tendões durante a aplicação da carga (Figuras 5, 6 e 7).

\section{RESULTADOS - TABELAS 2,3,4,5}

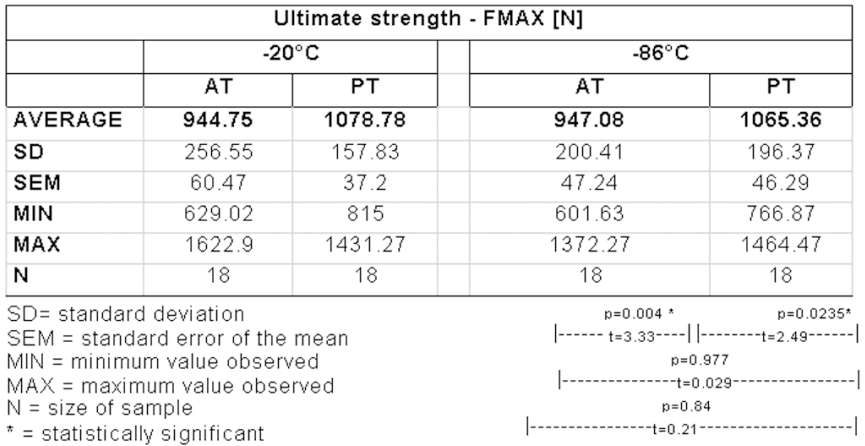

Tabela 2 - Comparação dos valores de Resistência Máxima (FMAX), medida em Newton, dos tendões dos músculos tibiais anteriores (TA) e tibiais posteriores (TP) congelados a $-20^{\circ} \mathrm{C}$ e a $-86^{\circ} \mathrm{C}$.

Table 2 - Comparison of ultimate strength values $\left(\mathrm{F}_{\mathrm{MAx}}\right)$ (newtons) of anterior tibial muscle tendons (AT) and posterior tibial muscle tendons (PT) frozen at minus $20^{\circ} \mathrm{C}$ and at minus $86^{\circ} \mathrm{C}$.

\begin{tabular}{|c|c|c|c|c|}
\hline \multicolumn{5}{|c|}{ Modulus of elasticty $(\varepsilon)$ [MPa] } \\
\hline & \multicolumn{2}{|c|}{$\mathbf{- 2 0 ^ { \circ } \mathbf { C }}$} & \multicolumn{2}{c|}{$\mathbf{- 8 6 ^ { \circ } \mathbf { C }}$} \\
\hline & AT & P T & AT & P T \\
\hline AVERAGE & $\mathbf{2 1 7 . 0 3}$ & $\mathbf{2 0 0 . 7 5}$ & $\mathbf{1 9 0 . 7 9}$ & $\mathbf{1 6 4 . 8 9}$ \\
\hline SD & 49.35 & 59.97 & 50.80 & 43.04 \\
SEM & 11.63 & 14.13 & 11.97 & 10.15 \\
MIN & 126.14 & 115.73 & 113.14 & 94.31 \\
\hline MAX & 319.06 & 333.43 & 274.71 & 266.75 \\
\hline N & 18 & 18 & 18 & 18 \\
\hline
\end{tabular}

$S D=$ standard deviation

$S E M=$ standard error of the mean

MIN = minimum value observed

MAX = maximum value observed

$N=$ size of sample

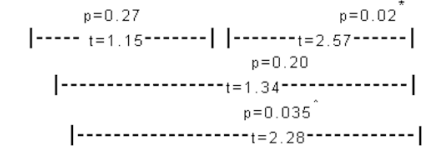

* = statistically significant

Tabela 4 - Comparação dos valores do Módulo de Elasticidade (E), medido em Megapascal, dos tendões dos músculos tibiais anteriores (TA) e tibiais posteriores (TP) congelados a $-20^{\circ} \mathrm{C}$ e a $-86^{\circ} \mathrm{C}$.

Table 4 - Comparison of modulus of elasticity (e) values (megapascals) of anterior tibial muscle tendons (AT) and posterior tibial muscle tendons (PT) frozen at minus $20^{\circ} \mathrm{C}$ and at minus $86^{\circ} \mathrm{C}$.

\section{DISCUSSÃO}

A idéia de estudarmos os tendões tibiais nos ocorreu pela facilidade de obtenção, uniformidade de estrutura e facilidade de manuseio. São tendões longos (comprimento médio de 25 $\mathrm{cm}$ ) e aparentemente resistentes (Figura 8).

0 estudo de cadáveres do sexo masculino com idade média relativamente baixa, se considerarmos que estudamos cadáveres que foram a óbito decorrente de causa não violenta, foi com a intenção de uniformizar ao máximo nossa amostra.

Conservamos metade das peças a menos $20^{\circ} \mathrm{C}$ e metade a menos $86^{\circ} \mathrm{C}$, a fim de compararmos as possíveis alterações sofridas pelos tendões quando armazenados na temperatura utilizada para estocagem dos materiais biológicos nos bancos de tecido, que é de cerca de menos $86^{\circ} \mathrm{C}$. $\mathrm{O}$ grupo de tendões

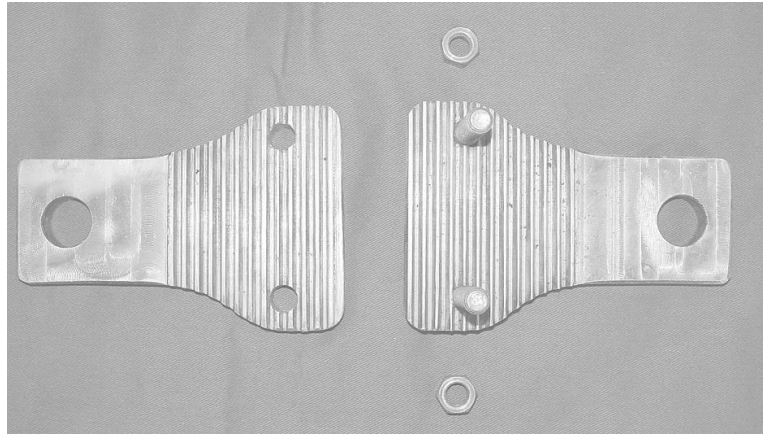

Figura 7 - Garras utilizadas no ensaio de tração

Figure 7 - Clamps used in the strain test

RESULTS - TABLES $2,3,4,5$

\begin{tabular}{|c|c|c|c|c|}
\hline \multicolumn{5}{|c|}{ Rigidity $[\mathrm{N} / \mathrm{mm}]$} \\
\hline & \multicolumn{2}{|c|}{$-20^{\circ} \mathrm{C}$} & \multicolumn{2}{|c|}{$-86^{\circ} \mathrm{C}$} \\
\hline & $\mathrm{AT}$ & $\mathbf{P T}$ & $\mathrm{AT}$ & $\mathbf{P T}$ \\
\hline AVERAGE & 109.85 & 117.02 & 148.74 & 119.41 \\
\hline SD & 14.04 & 25.99 & 13.55 & 15.07 \\
\hline SEM & 3.31 & 6.13 & 3.19 & 3.55 \\
\hline MIN & 80.14 & 68.5 & 100.68 & 101.83 \\
\hline MAX & 134.74 & 161.84 & 148.74 & 162.81 \\
\hline $\mathbf{N}$ & 18 & 18 & 18 & 18 \\
\hline \multicolumn{3}{|c|}{$\begin{array}{l}\text { SD = standard deviation } \\
\text { SEM = standard error of the mean } \\
\text { MIN = minimum value observed } \\
\text { MAX = maximum value observed } \\
N=\text { size of sample } \\
{ }^{+}=\text {statistically significant }\end{array}$} & $\begin{array}{l}p=0.31 \\
t=1.04\end{array}$ & $\begin{array}{l}\quad p=0.35 \\
t=0.96-\cdots \\
.025^{*} \\
45^{*}\end{array}$ \\
\hline
\end{tabular}

Tabela 3 - Comparação dos valores da Rigidez, medida em Newton por milímetro, dos tendões dos músculos tibiais anteriores (TA) e tibiais posteriores (TP) congelados a $-20^{\circ} \mathrm{C}$ e a $-86^{\circ} \mathrm{C}$.

Table 3 - Comparison of rigidity values (newtons per $\mathrm{mm}$ ) of anterior tibial muscle tendons (AT) and posterior tibial muscle tendons (PT) frozen at minus $20^{\circ} \mathrm{C}$ and at minus $86^{\circ} \mathrm{C}$.

\begin{tabular}{|c|c|c|c|c|}
\hline \multicolumn{5}{|c|}{$\varepsilon[\%]$} \\
\hline & \multicolumn{2}{|c|}{$-20^{\circ} \mathrm{C}$} & \multicolumn{2}{|c|}{$-86^{\circ} \mathrm{C}$} \\
\hline & AT & $\mathbf{P T}$ & AT & $\mathbf{P T}$ \\
\hline AVERAGE & 24.26 & 26.31 & 25.48 & 29.25 \\
\hline SD & 7.48 & 3.24 & 7.88 & 6.31 \\
\hline SEM & 1.76 & 0.76 & 1.86 & 1.49 \\
\hline MIN & 16.86 & 20.6 & 14.17 & 17.98 \\
\hline MAX & 48.27 & 31.62 & 48.52 & 36.93 \\
\hline $\mathbf{N}$ & 18 & 18 & 18 & 18 \\
\hline \multicolumn{3}{|c|}{$\begin{array}{l}\text { SD = standard deviation } \\
\text { SEM = standard error of the mean } \\
\text { MIN = minimum value observed } \\
\text { MAX = maximum value observed } \\
N=\text { size of sample } \\
{ }^{*}=\text { statistically significant }\end{array}$} & $\left|-\sum_{p=0.63}^{p=0.31}\right|_{t=1.06}^{p=0.043}$ & $\begin{array}{l}p=0.043 \\
0 .-1 \\
\cdots-.-1\end{array}$ \\
\hline
\end{tabular}

Tabela 5 - Comparação dos valores de alongamento máximo relativo (e\%), medido em porcentagem, dos tendões dos músculos tibiais anteriores (TA) e tibiais posteriores (TP) congelados a $-20^{\circ} \mathrm{C}$ e a $-86^{\circ} \mathrm{C}$.

Table $\mathbf{5}$ - Comparison of maximum relative elongation values $(\mathrm{e} \%)$

(percentage) of anterior tibial muscle tendons (AT) and posterior tibial muscle tendons (PT) frozen at minus $20^{\circ} \mathrm{C}$ and at minus $86^{\circ} \mathrm{C}$.

\section{DISCUSSION}

The idea of studying tibial tendons has occurred to us because they are easy to obtain, besides presenting uniform structures and being easy to handle. These are long (average length $25 \mathrm{~cm}$ ) and apparently resistant tendons (Figure 8 ).

The reason why we used male cadavers with a relatively low mean age, considering that their deaths were secondary to nonviolent causes, was to maximize the uniformity of our sample. 
armazenados a menos $20^{\circ} \mathrm{C}$ constituiu aquele que se assemelha ao estudo de peças a fresco, tendo em vista as dificuldades técnicas de se realizar este tipo de estudo com tendões frescos. 0 processo de descongelamento foi o mesmo que utilizamos para os procedimentos cirúrgicos em que utilizamos aloenxertos no nosso serviço.

Os tendões dos músculos tibial anterior e posterior preparados e armaze- Figura 8 - Peças anatômicas preparadas para o teste nados segundo estas técnicas habitu- mecânico, onde TA = tendão do músculo tibial anterior e TP a tendão do músculo tibial posterior.

ais foram submetidos a ensaios mecâ- Figure 8 - Anatomical pieces prepared for the mechanical nicos de tração. A metodologia de ava- test, where AT represents the anterior tibial muscle tendon liação das características mecânicas foi and PT represents the posterior tibial muscle tendon. a mais próxima dos padrões habituais da literatura, para tornar possível a comparação com eventuais estruturas a serem substituídas.

Foram estudadas as características mecânicas de resistência máxima, módulo de elasticidade, alongamento máximo relativo e rigidez nas temperaturas de menos $20^{\circ} \mathrm{C}$ e menos $86^{\circ} \mathrm{C}$. Os resultados demonstraram que há uma variação no comportamento mecânico dos dois tendões estudados.

Resumidamente, tivemos as seguintes diferenças estatisticamente significantes entre o TA e o TP:

- a resistência máxima do tibial posterior (TP) é maior que a do tibial anterior(TA) em ambas as temperaturas estudadas.

- o módulo de elasticidade do TA é maior que o do TP a menos $86^{\circ} \mathrm{C}$.

- 0 alongamento máximo relativo do TP é maior que o do TA a menos $86^{\circ} \mathrm{C}$.

- a rigidez do TA é maior a menos $86^{\circ} \mathrm{C}$ do que a menos $20^{\circ} \mathrm{C}$.

Comparamos os valores encontrados no nosso trabalho com os obtidos por autores que estudaram as mesmas características do ligamento cruzado anterior (LCA) segundo metodologia semelhante à que utilizamos.

Silvares ${ }^{(12)}$ e Hernandez ${ }^{(4)}$ encontraram resistência máxima do LCA de $875 \mathrm{~N} \pm 266 \mathrm{~N}$ e de $955 \mathrm{~N}$ respectivamente, que comparados aos valores de $947 \mathrm{~N} \pm 200 \mathrm{~N}$ do $\mathrm{TA}$ mantido a menos $86^{\circ} \mathrm{C}$ e $1065 \mathrm{~N} \pm 196 \mathrm{~N}$ do TP mantido a menos $86^{\circ} \mathrm{C}$, demonstram que os tendões tibiais podem substituir perfeitamente 0 LCA no que se refere à resistência máxima.

Se compararmos os valores obtidos por Silvares ${ }^{(12)}$ para a resistência máxima do tendão do músculo semitendíneo (ST) em conformação tripla $(988 \mathrm{~N} \pm 203 \mathrm{~N})$ e os obtidos por Müller ${ }^{(7)}$ para a resistência máxima do ligamento da patela com espessura de $10 \mathrm{~mm}$ aos valores do TP e do TA obtidos em nossos ensaios, verificamos que mesmo comparados a outros enxertos classicamente utilizados para as reconstruções de ligamentos do joelho, os tendões tibiais apresentam resistência semeIhante.

Os trabalhos citados foram realizados com máquinas de ensaio semelhantes à que utilizamos, especialmente na velocidade de aplicação de carga, em torno de $20 \mathrm{~mm}$ por minuto.

Nos trabalhos clássicos de Noyes et al. ${ }^{(8)}$, que encontraram $1725 \mathrm{~N} \pm 269 \mathrm{~N}$ para resistência máxima do LCA, $1216 \mathrm{~N} \pm 50 \mathrm{~N}$
Half of the pieces were kept at minus $20^{\circ} \mathrm{C}$ and the other half at minus $86^{\circ} \mathrm{C}$, in order to compare possible changes in the tendons when stored at the temperature employed in tissue banks to store biological materials, that is, minus $86^{\circ} \mathrm{C}$. Given the technical difficulties in performing this study with fresh tendons, we used a set of tendons stored at minus $20^{\circ} \mathrm{C}$, which is similar to the ones used in studies with fresh pieces. In this study we used the same thawing process as the one employed in the surgical processes for allografts in our Service.

The anterior and posterior tibial muscle tendons were prepared and stored according to usual techniques and subjected to strain mechanical tests. In order to make a comparison with other possible structures to be used as replacements, the methodology to evaluate the mechanical characteristics was kept as close as possible to the usual standards shown in the literature.

The following mechanical characteristics were studied, both at minus $20^{\circ} \mathrm{C}$ and minus $86^{\circ} \mathrm{C}$ : ultimate strength, elasticity modulus, maximum relative elongation, and rigidity. The results showed that the two studied tendons present different mechanical behaviors.

In summary, the following statistically significant differences were found in this study between ATs and PTs:

- the ultimate strength of the posterior tibial (PT) tendon is higher than that of the anterior tibial (AT) tendon at both temperatures employed.

- the modulus of elasticity of the AT is higher than that of the PT at minus $86^{\circ} \mathrm{C}$.

- the maximum relative elongation of the PT is higher than that of the AT at minus $86^{\circ} \mathrm{C}$.

- the rigidity of the AT tendon is higher at minus $86^{\circ} \mathrm{C}$ than at minus $20^{\circ} \mathrm{C}$.

We compared our results with the ones of other authors who investigated the same characteristics of the anterior cruciate ligament $(A C L)$ using a methodology similar to the one we used.

Silvares ${ }^{12)}$ and Hernande $z^{(4)}$ found for the $A C L$ ultimate strengths of $875 \mathrm{~N} \pm 266 \mathrm{~N}$ and $955 \mathrm{~N}$, respectively, which, as compared to the values of $947 \mathrm{~N} \pm 200 \mathrm{~N}$ found for the AT tendon kept at minus $86^{\circ} \mathrm{C}$ and $1065 \mathrm{~N} \pm 196 \mathrm{~N}$ for the PT tendon kept at minus $86^{\circ} \mathrm{C}$, show that both types of tibial tendons are perfectly capable of replacing the $A C L$ in terms of ultimate strength.

If we compare the results obtained by Silvares ${ }^{(12)}$ for the ultimate strength of the semitendinous (ST) muscle tendon in triple conformation ( $988 \mathrm{~N} \pm 203 \mathrm{~N}$ ) and those obtained by Müller ${ }^{(7)}$ for the ultimate strength of a $10-\mathrm{mm}$ thick patellar ligament to the PT and AT values obtained in our tests, it can be seen that the tibial tendons present a similar strength, even if we compare them to other grafts traditionally employed in knee ligament reconstructions.

The above-mentioned studies were performed with testing machines similar to the one we used, particularly in terms of loading speed, which is approximately $20 \mathrm{~mm}$ per minute. 
para a do ST e $2900 \mathrm{~N} \pm 516 \mathrm{~N}$ para a do LP de $14 \mathrm{~mm}$ de espessura, a velocidade utilizada foi de $3000 \mathrm{~mm}$ por minuto, fato que explica a diferença de valores, uma vez que estruturas viscoelásticas como os tendões e os ligamentos apresentam valores de resistência máxima à ruptura aumentados à medida que se aumenta a velocidade de aplicação de carga(6).

Observamos que as áreas de secção transversa dos tendões dos músculos tibiais posteriores são significativamente maiores do que a dos tibiais anteriores, independentemente do tipo de congelamento realizado, o que acreditamos tratar-se de uma característica anatômica destes tendões, naturalmente mais espessos do que os tibiais anteriores. Também observamos que as áreas de secção transversa dos tendões congelados a $-86^{\circ} \mathrm{C}$ são significativamente maiores do que as dos tendões frescos. A comparação dos resultados da área de secção transversa do TA e TP com os resultados do LCA, LP e SMT existentes na literatura(12) nos permite afirmar que os valores do TA e TP são semelhantes aos do LCA e SMT duplo $\left(34,0 \mathrm{~mm}^{2}\right.$ e $\left.26,0 \mathrm{~mm}^{2}\right)$, praticamente duas vezes maiores do que o SMT único $(10,8$ $\left.\mathrm{mm}^{2}\right)$ e cerca de duas vezes menores do que o LP $\left(37,0 \mathrm{~mm}^{2}\right)$ e o SMT quádruplo $\left(56,3 \mathrm{~mm}^{2}\right)$, o que nos permite dizer que uma preparação de enxerto duplicado de TA ou TP (ou mesmo a associação TA - TP) aparenta ser a conformação mais indicada para a substituição do LCA, tendo em vista os valores das áreas dos substitutos já consagrados pelo uso.

Se considerarmos que os tendões tibiais têm comprimento suficiente para sua utilização de forma dupla ou mesmo tripla na substituição do ligamento cruzado anterior, podemos concluir pela sua utilidade neste tipo de cirurgia reconstrutiva ${ }^{(3)}$.

A utilização do TA e do TP em outras cirurgias reconstrutivas, como em rupturas tendinosas crônicas, deverá ser analisada sempre comparando as suas características mecânicas às da estrutura a ser substituída.

\section{CONCLUSÃO}

As características mecânicas dos tendões dos músculos tibial anterior e posterior analisadas demonstram serem os dois tendões possivelmente úteis como aloenxertos na reconstrução do ligamento cruzado anterior do joelho.

\section{AGRADECIMENTOS}

\section{Dr Raul Bolliger Neto e César Augusto Martins Pereira}

\section{REFERÊNCIAS BIBLIOGRÁFICAS}

1. Arnoczky SP, Warren RF, Ashlock MA. Replacement of the anterior cruciate ligament using a patellar tendon allograft: an experimental study. J Bone J oint Surg Am 68:376-385, 1986.

2. Camanho GL, Olivi R. O uso do tendão do músculo semitendíneo fixo com "Endobutton" no tratamento das instabilidades anteriores do joelho. Rev Bras Ortop 31:369-372, 1996.

3. Haut Donahue TL, Howell SM, Hull ML, Gregersen C. A biomechanical evaluation of anterior and posterior tibialis tendons as suitable single-loop anterior cruciate ligament grafts. Arthroscopy 18: 589-597, 2002.

4. Hernandez AJ . Correlação das propriedades biomecânicas dos ligamentos do joelho com seus parâmetros antropométricos. [Doutorado]. São Paulo:Faculdade de Medicina, Universidade de São Paulo; 1994.

5. Insall J , J oseph DM, Aglietti P, Campbell RD. Bone-block iliotibial-band transfer for anterior cruciate insufficiency. J Bone J oint Surg Am 63:560-569, 1981.

6. Kennedy J C, Hawkins RJ, Willis RB, Danylchuk KD. Tension studies of human knee ligaments. Yield point, ultimate failure and disruption of the cruciate and tibial collateral ligaments. J Bone J oint Surg Am 58:350, 1976.

7. Müller SS. Análise comparativa das propriedades mecânicas do ligamento da patela e do tendão calcâneo : estudo experimental em cadáveres humanos. [Dou-
In their classical studies, Noyes et al (8) found $1725 \mathrm{~N} \pm 269$ $\mathrm{N}$ for the ultimate strength of the ACL, $1216 \mathrm{~N} \pm 50 \mathrm{~N}$ for ST and $2900 \mathrm{~N} \pm 516 \mathrm{~N}$ for a $14-\mathrm{mm}$ thick PL tendon using a $3000 \mathrm{~mm} /$ minute speed, a fact that explains the different values found, since viscoleastic structures such as tendons and ligaments show increased ultimate strength values with increased loading speeds $s^{(6)}$.

Iw was observed that the cross section areas of the posterior tibial muscle tendons are significantly larger than those of the anterior tibial ones, regardless the type of thawing employed, so we believe this is a typical anatomical feature of these tendons that are naturrally thicker than the anterior tibial tendons. We also noticed that the cross section areas of the tendons that were frozen at minus $86^{\circ} \mathrm{C}$ are significantly larger than those of fresh tendons. The comparison of the results of the cross section area of the Ats and PTs of the ACL, PL and TMS found in the literarure ${ }^{(12)}$ allows us to state that the values of TA and TP are similar to those of the ACL and double TMS $\left(34.0 \mathrm{~mm}^{2}\right.$ and $\left.26.0 \mathrm{~mm}^{2}\right)$, that is, virtually twice the size of the single TMS $\left(10.8 \mathrm{~mm}^{2}\right)$ and approximately half of the size of LP $\left(37.0 \mathrm{~mm}^{2}\right)$ and the quadruple TMS $\left(56.3 \mathrm{~mm}^{2}\right)$, which allows us to say that a preparation of a double graft of AT or PT (or even an association of both, TA TP) seems to be the most indicated conformation in the replacement of the $A C L$, given the values of the areas of the replacements already recognized by usage.

If we consider that tibial tendons are long enough to be used in a double or even triple form in the replacement of the anterior cruciate ligament, it is possible to reach the conclusion that tibial tendons are useful in this type of reconstruction surgery ${ }^{(3)}$.

The utilization of AT and PT in other reconstruction surgeries (such as chronic tend inous ruptures) should always be analyzed by comparing their mechanical characteristics to the ones of the structure to be replaced.

\section{CONCLUSION}

The mechanical characteristics of the anterior and posterior tibial muscle tendons that were analyzed show that possibly the two types of tendons are useful as allografts in knee anterior cruciate ligament reconstruction.

\section{ACKNOWLEDGEMENTS}

Dr Raul Bolliger Neto e César Augusto Martins Pereira

torado]. Botucatu: Faculdade de Medicina de Botucatu, Universidade Estadual Paulista; 1998.

8. Noyes FR, Grood ES. The strength of the anterior cruciate ligament in humans and Rhesus monkeys.J Bone J oint Surg Am 58:1074-1082, 1976.

9. Noyes FR, Barber-Westin S. Reconstruction of the anterior cruciate ligament with human allograft. J Bone J oint Surg Am 78:524-537, 1996.

10. Peterson RK, Shelton WR, Bomboy AL. Allograft versus autograft patellar tendon anterior cruciate ligament reconstruction: a 5-year follow-up. Arthroscopy 17:913, 2001.

11. Shino K, Kawasaki T, Hirose H, Gotoh I, Inoue M, Ono K. Replacement of the anterior cruciate ligament by an allogenic tendon graft. J Bone J oint Surg Br66:672681, 1984.

12. Silvares PRA. Análise das propriedades mecânicas do ligamento cruzado anterior, ligamento da patela e tendão do músculo semitendíneo triplicado: estudo em cadáveres humanos. [Doutorado]. Botucatu: Faculdade de Medicina de Botucatu, Universidade Estadual Paulista; 2001.

13. Vorlat $P$, Verdonk $R$, Arnauw G. Long-term results of tendon allografts for anterior cruciate ligament replacement in revision surgery and in cases of combined complex injuries. Knee Surg Sports Traumatol Arthrosc 7:318-322, 1999. 